\title{
MENGISI POLA GAMBAR DENGAN TEKNIK KOLASE MELALUI \\ METODE PEMBERIAN TUGAS UNTUK MENINGKATKAN \\ KEMAMPUAN MOTORIK HALUS PADA PESERTA DIDIK DI PAUD NEGERI PEMBINA KEC. RENGAT BARAT
}

\author{
Endang Widia \\ Surel: raja.panduwinata@yahoo.co.id
}

\begin{abstract}
Motor learning success can be achieved if teaching and learning takes place in a fun because that way the child's motivation will arise / rise up so that children have a strong curiosity and passion for learning. In the normal practice of collage, fine motor has not seemed to progress as they only use demonstration method in teaching. Kids less indicates a change in attitude since it tends to be passive and accept what the teacher so that the results obtained are less than the maximum. Therefore, the researcher trying to dig a way to teach learning fill pattern image with collage technique through the method of administration tasks can improve fine motor learners Group B TK Negeri Pembina Rengat District of West. In this PTK in the second cycle of activities "Fill pattern image with collage technique through the method of administration has the task can improve fine motor development of learners group B. It can be caused because the teacher has been creative in the presentation of learning.
\end{abstract}

Keyword: Collage Technique, Method of Providing Duty, Pattern Picture

\section{PENDAHULUAN}

Pengaruh globalisasi telah merambat ke berbagai bidang kehidupan termasuk bidang pendidikan. System pendidikan secara spontan harus mengikuti perubahan tersebut, terutama pada system kurikulum yang diberlakukan pada saat itu.

Kurikulum merupakan arah dan pegangan untuk mencapai tujuan pendidikan. Sekarang ini pendidikan mengalami kemajuan yang sangat pesat, berbagai upaya dan inovasi terus dilakukan pada setiap jenjang seiring dengan kebutuhan masyarakat dan peserta didik Paud khususnya. Keberhasilan pembelajaran motorik halus dapat terwujud apabila kegiatan belajar mengajar berlangsung secara menyenangkan karena dengan cara itu motivasi anak akan timbul/bangkit sehingga anak memiliki keingintahuan yang kuat, keberanian dan minat untuk belajar.

Dalam kegiatan praktik kolase, motorik halus anak selama ini belum tampak kemajuan karena hanya menggunakan metode demonstrasi dalam pembelajaran. Anak kurang menunjukkan perubahan sikap karena cenderung pasif dan menerima apa yang diberikan guru sehingga hasil yang diperoleh kurang maksimal, oleh sebab itu dalam PTK ini penulis mencoba menggali cara mengajarkan pembelajaran "mengisi pola gambar 
dengan teknik kolase melalui metode pemberian tugas dapat meningkatkan motorik halus peserta didik TK Negeri Pembina Kecamatan Rengat Barat Kelompok B.

Peneliti melakukan penelitian dalam dua siklus. Tujuannya adalah untuk membuktikan bahwa dengan metode pemberian tugas mengisi pola gambar dengan teknik kolase dapat meningkatkan motorik halus anak TK. Hal ini ternyata dapat peneliti buktikan setelah penulis laksanakan dalam 2 siklus.

\section{METODE PENELITIAN}

Penelitian ini merupakan jenis Penelitian Tindakan Kelas. Penelitian di laksanakan di TK Pembina di Kec. Rengat Barat Kabupaten Indragiri Hulu Provinsi Riau. Pelaksanaan perbaikan siklus 1 dilaksanakan dengan rentang waktu dari tanggal 07 Oktober sampai 11 Oktober 2014.

Tabel I: Jadwal Pelaksanaan Perbaikan Siklus 1

\begin{tabular}{|c|l|l|}
\hline NO & \multicolumn{1}{|c|}{ HARI/TANGGAL } & \multicolumn{1}{|c|}{ KEGIATAN } \\
\hline 1 & Senin, 07 Oktober 2014 & $\begin{array}{l}\text { Mengisi pola gambar gelas dengan } \\
\text { guntingan kertas }\end{array}$ \\
\hline 2 & Selasa, 08 Oktober 2014 & Mengisi pola gambar dengan kacang hijau \\
\hline 3 & Rabu, 09 Oktober 2014 & $\begin{array}{l}\text { Mengisi pola gambar balon dengan kain } \\
\text { perca }\end{array}$ \\
\hline 4 & Kamis, 10 Oktober 2014 & $\begin{array}{l}\text { Mengisi pola gambar kincir dengan pipet } \\
\text { dan kacang hijau. }\end{array}$ \\
\hline 5 & Jum'at, 11 Oktober 2014 & $\begin{array}{l}\text { Mengisi pola gambar laying-layang dengan } \\
\text { kertas, kacang hijau, dan daun kering. }\end{array}$ \\
\hline
\end{tabular}

Pelaksanaan perbaikan pada siklus II akan dilaksanakan pada tanggal 14-18 Oktober 2014 dengan tema alat komunikasi pada anak TK Negeri Pembina Kelompok B. Siklus ke II ini tetap dilaksanakan sesuai siklus 1 yaitu perencanaan, pelaksanaan, pengamatan dan diharapkan anak mencapai bintang 4 $(* * * *)$.

Tabel II: Jadwal Pelaksanaan Perbaikan Siklus II Tema Alat Komunikasi

\begin{tabular}{|c|c|l|}
\hline NO & \multicolumn{1}{|c|}{ HARI/TANGGAL } & \multicolumn{1}{|c|}{ KEGIATAN } \\
\hline 1 & Senin, 14 Oktober 2014 & $\begin{array}{l}\text { Mengisi pola gambar HP dengan gunting } \\
\text { dan kertas }\end{array}$ \\
\hline 2 & Selasa, 15 Oktober 2014 & $\begin{array}{l}\text { Mengisi pola gambar TV dengan pipet dan } \\
\text { daun kering }\end{array}$ \\
\hline 3 & Rabu, 16 Oktober 2014 & $\begin{array}{l}\text { Mengisi pola gambar Telepon dengan } \\
\text { kacang hijau }\end{array}$ \\
\hline
\end{tabular}




\begin{tabular}{|c|l|l|}
\hline 4 & Kamis, 17 Oktober 2014 & $\begin{array}{l}\text { Mengisi pola gambar radio dengan pipet } \\
\text { dan kertas }\end{array}$ \\
\hline 5 & Jum'at, 18 Oktober 2014 & $\begin{array}{l}\text { Mengisi pola gambar amplop surat dengan } \\
\text { Koran dan kadang hijau }\end{array}$ \\
\hline
\end{tabular}

\section{HASIL DAN PEMBAHASAN}

Tabel III: Data Awal Pengamatan Kegiatan Pengembangan Kelompok B

\begin{tabular}{|c|l|c|c|c|c|c|c|c|c|c|}
\hline \multirow{2}{*}{ NO } & \multirow{2}{*}{ HARI/TANGGAL } & \multicolumn{3}{|c|}{ Hasil dan Jumlah Anak } & \multicolumn{4}{|c|}{ Persentase } & Ket \\
\cline { 3 - 12 } & $*$ & $* *$ & $* * *$ & $* * * *$ & $\%$ & $\%$ & $\%$ & $\%$ & \\
\hline 1 & $\begin{array}{l}\text { Senin, 07 Oktober } \\
2014\end{array}$ & 4 & 13 & 1 & 0 & 22,4 & 72,8 & 5,6 & 0 & \\
\hline
\end{tabular}

Keterangan:

Bintang 1 belum berkembang

2 mulai berkembang

3 berkembang sesuai harapan

4 berkembang sangat baik

Tabel IV: Data Hasil Kegiatan Perbaikan Siklus 1 Tema: Air, Udara, dan Api pada Kelompok B

\begin{tabular}{|c|c|c|c|c|c|c|c|c|c|c|}
\hline \multirow{2}{*}{ NO } & \multirow{2}{*}{ HARI/TANGGAL } & \multicolumn{5}{|c|}{ Hasil dan Jumlah } & \multicolumn{5}{|c|}{ Persentase } & \multirow{2}{*}{ Ket } \\
\cline { 3 - 11 } & & $*$ & $* *$ & $* * *$ & $* * * *$ & $\%$ & $\%$ & $\%$ & $\%$ & \\
\hline 1 & Senin, 07 Oktober 2014 & 3 & 12 & 3 & 0 & 16,8 & 67,2 & 16,8 & 0 & \\
\hline 2 & Selasa, 08 Oktober 2014 & 3 & 11 & 4 & 0 & 16,8 & 61,2 & 22,4 & 0 & \\
\hline 3 & Rabu, 09 Oktober 2014 & 2 & 12 & 4 & 0 & 11,2 & 67,2 & 22,4 & 0 & \\
\hline 4 & Kamis, 10 Oktober 2014 & 2 & 11 & 5 & 0 & 11,2 & 61,6 & 28 & 0 & \\
\hline 5 & Jum'at, 11 Oktober 2014 & 2 & 10 & 6 & 0 & 11,2 & 36 & 33,6 & 0 & \\
\hline
\end{tabular}

Keterangan:

Bintang 1 belum berkembang

2 mulai berkembang

3 berkembang sesuai harapan

4 berkembang sangat baik 
Tabel V Data Hasil Kegiatan Perbaikan Siklus II Tema Komunikasi

\begin{tabular}{|c|l|c|c|c|c|c|c|c|c|c|}
\hline \multirow{2}{*}{ NO } & \multirow{2}{*}{ HARI/TANGGAL } & \multicolumn{3}{|c|}{ Hasil dan Jumlah Anak } & \multicolumn{5}{|c|}{ Persentase } & Ket \\
\cline { 2 - 10 } & $*$ & $* *$ & $* * *$ & $* * * *$ & $\%$ & $\%$ & $\%$ & $\%$ & \\
\hline 1 & $\begin{array}{l}\text { Senin, 14 Oktober } \\
2014\end{array}$ & 2 & 10 & 6 & - & 11,2 & 56 & 33,6 & - & \\
\hline 2 & $\begin{array}{l}\text { Selasa, 15 Oktober } \\
2014\end{array}$ & 1 & 6 & 10 & 1 & 5,6 & 33,6 & 56 & 5,6 & \\
\hline 3 & $\begin{array}{l}\text { Rabu, 16 Oktober } \\
2014\end{array}$ & 1 & 5 & 10 & 2 & 5,6 & 28 & 56 & 11,2 & \\
\hline 4 & $\begin{array}{l}\text { Kamis, 17 Oktober } \\
2014\end{array}$ & - & 4 & 11 & 2 & 0 & 22,4 & 61,6 & 11,2 & \\
\hline 5 & $\begin{array}{l}\text { Jum'at, 18 Oktober } \\
2014\end{array}$ & - & 3 & 11 & 3 & 0 & 16,8 & 61,6 & 16,8 & \\
\hline
\end{tabular}

Pada siklus kedua peserta didik dalam pengembangan motorik halusnya khususnya dalam mengisi pola sudah lebih meningkat. Peserta didik telah memperoleh bintang 4 (****). Jadi dapat disimpulkan bahwa mengisi pola gambar dengan teknik kolase melalui pemberian tugas dapat meningkatkan pengembangan motorik halus anak.

\section{KESIMPULAN}

Berdasarkan pemaparan persiklus dapat disimpulkan bahwa:

1. Pada siklus 1 perkembangan motorik halus anak belum begitu meningkat. Hal ini disebabkan karena anak belum begitu termotivasi untuk melakukan kegiatan tersebut, karena masih tergolong rumit.

2. Sementara pada siklus II pengembangan motorik halus anak mulai adanya peningkatan. Melalui metode pemberian tugas anak tampak lebih kreatif dalam menyusun berbagai benda pada gambar yang tersedia dan anak bias memperoleh nilai bintang 4 $(* * * *)$.

Jadi dapat dikatakan bahwa "pembelajaran yang dibangun dengan kreatifitas guru dengan menggunakan metode yang cocok akan dapat meningkatkan kemampuan anak.

\section{DAFTAR RUJUKAN}

Arikunto, Suharsini. 1995. Manajemen Penelitian Jakarta: Rineka Cipta.

Masitoh, dkk. (2008). Strategi Pembelajaran TK. Jakarta: Universitas Terbuka.

Montolulu, B.E.F, dkk. (2008). Bermain dan Permainan Anak. Jakarta: Universitas Terbuka.

Nasir. Moh. 2003. Metode Penelitian. Jakarta: Ghalia Indonesia.

Santoso. (2010). Pendidikan dan Latihan Profesi Guru. Pekanbaru: Kementrian Pendidikan Nasional-Fkip UNRI. 